\title{
Public-Public Partnerships: The Role of Slovenian Local Authorities in Carrying out the Joint Tasks
}

\author{
BOJAN ŠKOF \& NELI BRADASCHIA
}

\begin{abstract}
Despite the clearly specified conditions laid down in the Slovenian Local Self-Government Act, both in theory and practice, the question often arises whether or not the Slovene municipalities are able to perform original tasks. In this regard, it must be noted that the local communities, i.e., municipalities and wider selfgoverning local communities, are not formed on the basis of certain criteria of rationality according to which it would be possible to prejudge whether or not they are capable of performing the tasks that they must perform, namely, the local public services. Today's municipalities are mostly the result of the historical development, traditions, political compromises, geographical and other factors that have nothing to do with the criteria of rationality with regard to the tasks and needs they must carry out and satisfy. Due to a large number of relatively weak local communities in Slovenia, the cooperation between them is important in carrying out the functions that are common to municipalities, to the state or to the EU. It is about public-public partnerships where local communities can play a key role because they know the needs of the local population.
\end{abstract}

KEYWORDS: • local authorities $\bullet$ local self-government $\bullet$ joint tasks public-public partnership $\bullet$ Slovenia

CORRESPONDENCE AdDRESS: Professor Bojan Škof, Ph. D., University of Maribor, Faculty of Law, Mladinska ulica 9, 2000 Maribor, Slovenia, email: bojan.skof@unimb.si. Neli Bradaschia, BSc., Institute for Local Self-Government and Public Procurement Maribor, Grajska ulica 7, 2000 Maribor, Slovenia, email: neli.bradaschia@lex-localis.info. 
The perceived deficiencies of undue state functioning, shown by high costs and prices of goods and services, public enterprise losses, and investment inefficiency gradually led to the fact that in the 1980 s, the majority of developed economies attempted to reduce the economic role of the state primarily through the processes of deregulation and privatisation of the public sector. This was quite understandable because the countries with high rates of technological progress and with high levels of national budget debt were not able to meet the growing needs of citizens. With the development of various modes of carrying out public service activities, the states increasingly involved the private sector in financing the construction of new infrastructure facilities, their management, and the carrying out of public service activities. By doing so, the role of the state changed significantly because the private sector increasingly began to assume both the fund-provider role in financing the public infrastructure and the role of a public service provider. On the other hand, the state began to strengthen its role in the fields of regulation and control. (Mrak, 2002: 2) By involving the private sector in the so-called project financing of investments in the construction of infrastructure facilities, and consequently in carrying out public service activities, some new and innovative forms of cooperation between the public and private sectors were gradually introduced (the so-called public-private partnership). At the same time, in addition to classical budgetary financing, countries gradually introduced new modes of public service financing. They allowed repayment of investment in public infrastructure, and repayments made to private providers of goods and services (public goods). In parallel with the development of various forms of public-private partnerships, in practice, we can see an alternative to privatisation and deregulation of public service activities. It is about the development of various forms of cooperation within the public sector, e.g., a public-public partnership that combines various forms of cooperation and integration between public sector entities to finance investment in public infrastructure and/or to carry out joint tasks.

\section{Local Self-Government in Slovenia}

Slovenia is now territorially divided into 210 municipalities. With an average number of inhabitants $(10,300)$ per municipality, our country is somewhere in the middle as compared to other EU Member States. However, it needs to be emphasized that the number of inhabitants per municipality ranges from 359 inhabitants in the Hodoš Municipality (according to the data from 2006) to 265,643 inhabitants in the capital, i.e., in the City Municipality of Ljubljana. There are even six municipalities in which fewer than 1000 inhabitants live. Most municipalities have between 1000 and 5000 inhabitants (50\%). Then there are municipalities that have from 10,000 to 100,000 inhabitants (23.8\%) out of which the largest Municipality of Kranj has 52,870 inhabitants. And there are only two municipalities that have more than 100,000 inhabitants (Ljubljana with 265,643 
inhabitants and Maribor with 112,627 inhabitants). In comparison with other EU Member States, we have quite numerous municipalities whose boundaries are not rationally set (see Brezovnik \& Oplotnik, 2003: 137-143; Oplotnik \& Bradaschia, 2005). Such diversity among the municipalities themselves and an inadequate model for financing the municipalities in Slovenia can lead to an inability to carry out their original tasks. The logical consequence would be either the integration of municipalities, which is, in terms of achieving political compromises, unrealistic to expect or the establishment of broader social communities to which the state would delegate carrying out the tasks of broader importance. This has not yet occurred despite the recent constitutional amendment. In 2006, the National Assembly of the Republic of Slovenia amended Article 143 of the Slovene Constitution, which until then determined that the 'municipalities independently decide on integration into wider self-governing local communities, also into regions, to regulate and perform local matters of broader importance...' However, despite some attempts, municipalities failed to link into wider self-governing communities. With the amendment of Article 143 of the Constitution of the RS, the obligation to establish regions passed to the National Assembly, which failed to establish them due to political disagreements, although, in experts' opinion, their establishment would be necessary.

The arguments in favour of medium-sized municipalities can also be found in the specialized literature where poor administration is mentioned as one of the drawbacks of too small municipalities (Tanzi, 2001; Tanzi, 2008). The problem of poor administration is also characteristic of the Slovene municipalities. According to the data from March 2006, 4,184 public employees were employed in 193 Slovene municipalities. However, the number of employees and their structure were different from municipality to municipality. Thus, there were scarcely populated municipalities in which either no employees were employed in municipal administration (e.g., the Jezersko Municipality) or the number of employees was small (e.g., 2 employees in the Osilnica Municipality; 3 employees in the following municipalities: Bloke, Hodoš, Luče, etc.). And there were municipalities where over 50 employees were employed in municipal administration. For example, the Domžale Municipality had 57 employees, the City Municipality of Maribor had 249 employees, and the City Municipality of Ljubljana had 550 employees. In 193 Slovene municipalities there were $23.3 \%$ of them that had up to 5 employees; $54.4 \%$ of municipalities had up to 25 employees; $15 \%$ of municipalities had up to 50 employees, and $7.3 \%$ of municipalities had more than 50 employees in 2006. On average, 2.09 employees are employed in municipal administration per 1,000 inhabitants in Slovenia. However, the following municipalities most stand out from the indicated average number: Jezersko (no employees employed per 1,000 inhabitants), Šenčur (1 employee), Brezovica (1 employee) etc. But on the other hand, the Kobilje Municipality has 11 employees per 1,000 inhabitants, the Hodoš Municipality has 8 employees, the Kostel Municipality has 8 employees, etc. 
To efficiently carry out municipal tasks and thereby satisfying the needs of the local population, it is of essential importance to have an efficient administrative system with an adequate number of professionally trained employees. Proceeding from the above mentioned, the ability to carry out original and delegated tasks of municipalities depends more on the actual than on normative realities of an individual local community. It is true that local communities are established on a normative basis. However, the establishment of narrower local communities does not often follow the rationality principle. In the light of exercising municipal competences, the local community financing system is of essential importance, which means that upon deciding on the scope of municipal tasks, the state has to establish such a local community financing system that will ensure appropriate and quality performance of local community tasks.

The matters which a municipality can autonomously regulate and which refer only to the residents of the municipality fall within the municipal competence in Slovenia (Article 140 of the Constitution of the Republic of Slovenia). With the prior consent of a municipality or a wider self-governing local community, the state may, by law, delegate individual tasks from the state competence to a municipality or to a wider self-governing local community if the state provides the necessary funds for this. However, this has not yet happened in Slovenia. The basic criterion for determining what is in the competence of municipalities and what falls within the state competence is the constitutional provision that says that these are all the local matters that can be autonomously regulated by the municipality, and that these matters refer only to the residents of the municipality. It is primarily about those matters that are mainly aimed at determining or providing normal living conditions in a local community. The criterion for determining the original tasks of municipalities is the obligation to meet the population's common needs and interests, which is also the condition for establishing municipalities under the provisions of the applicable Local SelfGovernment Act (Jerovšek, 1994: 48-50). In accordance with the Local SelfGovernment Act, it is considered that the municipality is capable of satisfying the needs and carrying out the tasks in accordance with the law if the following conditions are met: a) full primary school, b) primary health care for local residents (health centre or health station), c) utility infrastructure (drinking water supply, drainage and wastewater treatment, power supply), d) postal services, e) general or school library, and f) premises for administrative activities in the local community. These conditions indicate that the municipality must actually be able to provide the 'basic' goods and services that are the objects of carrying out the services of general interest. In its competence, the municipality has all the functions that are vital for the life and work of people in the municipal area. These functions are performed much more rationally and more efficiently in a local community than through the central authority (Šturm, 2002: 960). But in practice, due to the continuing delegation of new 'original' competences to municipalities, 
a sharp boundary between the original and delegated competences of municipalities or the separation of the two administrative systems, i.e., the separation of the state administration and local self-government established by the state, are disappearing (Juvan Gotovac, 2004: 151; Brezovnik, Juvan Gotovac \& Bradaschia, 2004).

Despite the clearly specified conditions laid down in the Local Self-Government Act, both in theory and practice, the question often arises whether or not the Slovene municipalities are able to perform original tasks. In this regard, it must first be noted that the local communities, i.e., municipalities and wider selfgoverning local communities (like the state itself), are not formed on the basis of certain criteria of rationality according to which it would be possible to prejudge whether or not they are capable of performing the tasks that they must perform, namely, the local public services. Today's municipalities are mostly the result of the historical development, traditions, political compromises, geographical and other factors that have nothing to do with the criteria of rationality with regard to the tasks and needs they must carry out and satisfy (Grafenauer, 2000).

Due to a large number of relatively weak local communities, the cooperation between them is important in carrying out the functions that are common to municipalities, to the state or to the EU. It is about public-public partnerships where local communities can play a key role because they know the needs of the local population.

\subsection{Public-Public Partnership}

Neither uniform nor common public-public partnership definition can be found in literature. Nevertheless, this concept combines various forms of cooperation and integration between public sector persons in financing investments in public infrastructure and / or in carrying out public services. Despite the non-uniform definition, the public-public partnerships can be classified according to the different types of partners who are involved in a partnership, and with regard to the partnership objectives.

According to the public-public partnership definition, which is most frequently used in the EU, the public-public partnership refers to the cooperation between two or more authorities, or between legal persons under public law within a country (Lobin \& Hall, 2006; 7). So, it can be horizontally established at the same level of authority (e.g., between local communities; inter-municipal co-operation), or vertically between different levels of authority (e.g., between the state and a local community). Public-public partnership is not territorially restricted to only public law entities (the state, regions, provinces, municipalities), but it can also be established between public law entities and other entities of public law (specialized entities of public law, such as public enterprises, public funds, public institutions, etc.), or only between other entities of public law. 
In addition to the forms of cooperation mentioned above, development partnerships can also be established. They are supranational. They include such forms of cooperation that can be established between public law entities from different countries or between public law entities of a country and the international community such as the EU (Hall, Lethbridge \& Lobina, 2005: 4).

The partnerships between two or more public law entities within a country are very frequent and usual. Two or more public law entities can cooperate between themselves either in financing investments in public infrastructure or in carrying out public services, or in performing other joint tasks. Such forms of public-public partnerships can be found in nearly all EU Member States. The reasons for such a cooperation lie either in streamlining the organisation, management and supply of public goods or in joint ventures in infrastructure that contribute to carrying out more quality public services (e.g., joint construction of a municipal waste- and rain-water treatment plant).

At this point, it needs to be noted that several EC policies (within the framework of the structural European Community policy) attempt to strengthen the forms of horizontal and vertical cooperation primarily between local and regional authorities (e.g., Leader and Interreg). However, it needs to be indicated that the administrative regulation of carrying out the joint tasks limits the capability of the regional and local authorities in carrying out the joint tasks, which raises issues regarding the consistency in the EC activities (Vandamme,2004; 139-140).

Several forms of cooperation between the regional and local authorities are used in the EU Member States in organising or carrying out the joint tasks. On the one hand, the main differences are based on the cooperating partners (horizontal cooperation where partners operate at the same level; vertical cooperation where they operate at different levels, and joint cooperation where there is a combined horizontal and vertical cooperation, and / or the involvement of private partners). But on the other hand, the cooperation procedures are taken into account. They have established themselves differently in different countries. These procedures have become part of the institutional structure.

\subsubsection{Horizontal Cooperation in Carrying out the Joint Tasks}

The horizontal cooperation in carrying out the joint tasks refers to the forms of cooperation or partnership developed by the regional or local authorities that operate at the same level with the same powers (usually with comparable resources) and with the partners at the same level (Levrat, 1994: 86-96). Such partnerships are reflected: in the coordination of the policies among different authorities without establishing a legal entity, or in establishing an independent specialised legal entity of public law (Vandamme, 2004; 139-140). 
Within the framework of the forms of horizontal cooperation in carrying out public services, it needs to be pointed out to various forms of inter-municipal cooperation. Such forms of horizontal cooperation, which are used for performing the joint tasks at the basic unit level of the local self-government, have been known in the local self-government systems of the European countries for more than a hundred years.

In so doing, as a rule, the laws do not interfere with the functional competent personality of the local self-government at the fundamental level. The promotion of inter-municipal cooperation has gone into two directions in the normative field. The first direction (at the federal level in Austria and in Italy) is statutory standardisation of the compulsory creation of the communities for specific tasks. The other direction (in Belgium, Germany - Bavaria, Sweden, the Netherlands, Finland) has gone into the direction of promoting voluntary integration of municipalities for specific tasks. A special example is the French inter-municipal cooperation that has grown on the basis of single-purpose communities that have (with multi-purpose communities, districts and communities of municipalities [in French, communautés de communes]) overgrown all similar movements by types and by number in the field of institutional inter-municipal cooperation.

In all the countries mentioned above, inter-municipal cooperation is institutionalised and it represents an independent legal entity of public law that executes municipal affairs for its founders who themselves do not carry out these tasks any longer. Organisationally speaking, all forms have a representative body (as a rule, it is constituted on a parity basis and indirectly) and an administrative system or organisation. It needs to be emphasized that in the case of institutions of inter-communal cooperation, as defined in the laws of the EU Member States, it is not about the creation of administrative systems for new 'larger' local communities, but it is about the local self-governments of the same kind.

The institutionalisation of inter-municipal cooperation can be found also in the Slovene legal regulation of local self-government. The applicable Local SelfGovernment Act provides that the local self-governing communities may voluntarily participate in joint regulation and execution of local affairs of public importance (so, also in performing services of general interest). For this purpose, they can pool resources and in accordance with the law, they may set up joint bodies and the bodies of the joint municipal administration; they can set up and manage funds, public institutes, public enterprises and institutions; they can link into communities and associations. The stated provision is general, and in accordance with the MELLS principles, it represents the principle (regulated by statute) of voluntary cooperation of local self-governing communities.

In accordance with the above, two or more municipalities may decide to establish one or more bodies of joint municipal administration. A joint municipal administration body or a joint municipal service board for performing individual 
tasks of the municipal administration are established by municipal councils on the basis of the general act adopted in the same text and with which they determine the tasks and internal organisation of the joint municipal administration. Thus, two or more municipalities can decide to set up an administrative department of public utilities (within the joint municipal administration for carrying out the local commercial public services) that can be either independent or dependent, and a public institution with no legal entity status for carrying out local non-commercial public services. This form of integration between municipalities is stimulated by the state because additional funds from the state budget are ensured for the municipality to carry out individual tasks in the provision and implementation of public services organised within the framework of the joint municipal administration. The state budget funds are provided in the amount of $50 \%$ of the realized last-year's expenditure of its budget for financing the organised joint performance of individual municipal administrative tasks. The municipality is eligible for those funds if the tasks are performed for two or more municipalities, and the tasks are carried out by the employees who meet the legally defined conditions for professional education.

Due to more economical and efficient provision of public services, two or more municipalities may jointly establish a specialised public entity, i.e., a public institution or company (see Brezovnik, 2009; Grafenauer, 2009). In this case, the municipalities founders must establish a joint body made up of mayors. This body is needed for coordinating the municipal decisions relating to the provision of public services. Upon establishing the joint body, the Local Self-Government Act allows municipal councils to delegate their powers (relating to the implementation of the founding rights) to this body, which can be constitutionally questionable. Under the provisions of the Local Self-Government Act, the municipal council is the highest decision-making body that decides on all the matters within the framework of the rights and duties of a municipality. Within its powers, the municipal council, inter alia, adopts ordinances and other municipal documents with which it regulates municipal public affairs. But the mayor represents the municipality. By delegating the powers relating to the implementation of the founding rights, both the special founders' rights and the regulatory powers are frequently delegated due to imperfect regulation of the relationship between the founder (municipality) and the specialised public entity (a public institution or enterprise). The delegation of regulatory powers is particularly controversial because the regulatory powers of a municipality are, by their legal nature, its public law entitlements in relation to all the commercial public service providers, not just to those whose founder the municipality is. So, the Local SelfGovernment Act actually allows the mayors of the municipalities-founders to make decisions about the regulation of a public service activity.

In addition to a public-public partnership in jointly establishing public institutions and enterprises for the purpose of economical and efficient public service performance, we also need to mention interest associations of municipalities. They 
can be established by two or more municipalities to jointly regulate and perform individual administrative tasks, and to carry out joint development and investment programmes. There can be either single-purpose or multi-purpose interest associations of municipalities. They have the status of legal entities of public law. A single-purpose interest association can be established for the joint performance of individual tasks (e.g., providing drinking water supply, planning, construction and management of a sewage treatment plant, etc.). A multi-purpose interest association can be established to perform most activities of local public services. An interim administrative system of inter-municipal cooperation can be established through these associations. It is neither a special local community nor the institution above the municipality level, but it is merely a mechanism or instrument for carrying out municipal tasks. The reasons for establishing an association can be either financial (pooling funds to finance joint investments in public infrastructure) or there can be professional technical reasons (to perform administrative tasks). At this point, it needs to be noted that the tasks, imposed by a municipality on an association, are no longer provided by the municipality itself. Therefore, through its representatives, the municipality participates in the association council that performs part of the tasks from the municipal council in the structure of local authorities.

The Local Self-Government Act specifically determines the interest association organisation. Thus, the council is constituted of a certain number of municipal council representatives of the municipalities-founders in accordance with the Association Establishment Act. Each municipality founder must have at least two members, but none may have more than half of the members. The interest association is established under the Deed of Foundation that the founders deposit with the Ministry for Local Self-Government for safekeeping. This document is published by the mayors of the municipalities-founders in the Official Journal of the RS. It is the basis for obtaining the legal personality of the interest association. Under the Deed of Foundation, the following shall be determined: association name and address; the tasks to be regulated and carried out by the founders of the association, operation start and termination, powers; composition, organisation and mode of decision-making in the council, providing funds for the association operation and for performance of tasks, association representation; the rights, obligations and responsibilities of founders; the regulation principles of their property and other relationships. Under the Deed of Association Formation, the regulations and other acts from the powers of municipal bodies are determined within the framework of the tasks performed by the municipalities in the association. The association's council shall be responsible for adopting regulations and other acts after establishing the association of municipalities (Brezovnik, 2007: 22-26). 


\subsubsection{Vertical Cooperation in Carrying out the Joint Tasks}

Vertical cooperation refers to forms of cooperation at different levels (the EU, the state and local communities). Vertical cooperation includes partners operating at different levels. But on the other hand, joint cooperation includes a number of partners operating at the same level, and at least one partner operating at a different level. In practice, such cooperation is reflected: - in the establishment of a joint entity (legal person) - in cooperation based on fund transfer, and $\cdot$ in contractual cooperation.

In addition to various forms of vertical cooperation between the authorities aiming at the establishment of a joint (specialised) legal person, we can find cases in practice where also private partners are involved in establishing the specialised legal entities. By involving private partners, public service performance is provided on the business principle thereby simultaneously providing the public interest, which falls within the powers of public partners.

In practice there is often cooperation based on fund transfer. In its structure, it is mainly vertical. This kind of cooperation is usually associated with financing investments in public infrastructure.

Contractual cooperation is especially important in the vertical structure. It is about the cooperation in the public service performance in which various tiers of authorities are involved. Depending on the national legislation, the contracts (target-based contracts, supply contracts and partnership contracts) are based either on public or private law. This kind of cooperation is also encouraged by the European Commission. In its White Paper on European Governance (COM (2001) 478, 25.7.2001), it attempted to submit a proposal that tripartite contracts should be concluded between the Commission (acting in the name of the EC), a Member State and one or more regional or local authorities. However, that proposal is rather utopian because (judging by the case law of the EC Court of Justice) the Court does not recognize any responsibility of local and regional authorities. The responsibility lies with the state whose integral parts these authorities are.

In its report of 11 December 2002 entitled 'A framework for target-based tripartite contracts and agreements between the Community, the States and regional and local authorities', the European Commission concedes that an insertion should be made 'in the wording of the contract itself, a provision aimed at recalling that the Member State in which the tripartite contract is performed is alone responsible vis-à-vis the Commission for its due performance and, consequently, subject to possible legal action pursuant to Article 226 of the Treaty'. It goes without saying that in such circumstances when it comes to the lack of legal liability on the part of one of the partners (the local or regional authority), it is inappropriate to refer to a tripartite contractual relationship. 
In any case, the basis of these contracts is the performance of certain tasks in the public interest by one or more parties in accordance with the conditions laid down in the contract and in exchange for co-funding by other contractors. Restricting the capacity of funding certain services would therefore lessen interest in using the methods of cooperation. (Vandamme, 2004; 139-140)

\subsubsection{Cross-Border Cooperation in Carrying out the Joint Tasks}

Within the framework of the public-public partnership in carrying out the joint tasks, cross-border cooperation also needs to be mentioned. The general legal framework for such cooperation in the European legal space is determined by the European Outline Convention on Cross-Border Cooperation between Territorial Communities or Authorities concluded in Madrid, 21 May 1980 (under the auspices of the Council of Europe), and was ratified by Slovenia in 2003. However, the Convention does not set out the procedures for cross-border cooperation. They are determined by the sample model and outline agreements, statutes and contracts that are added to the Convention (they are of purely informative nature). It is interesting to note that the original convention did not recognise the right of local and regional authorities to establish cross-border cooperation. However, under the convention, 'each contracting party undertakes to facilitate and foster cross-border cooperation between territorial communities or authorities that are under its jurisdiction, and territorial communities or authorities that are under jurisdiction of other contracting parties'. It is clear that this is not enough to establish cross-border cooperation in carrying out the joint tasks. Furthermore, a study carried out by the Secretariat of the Council of Europe in 1990, i.e., ten years after the Outline Convention was opened for signing, shows that in the practice of the countries signatories, the proposed outline agreements, statutes and contracts have not been used.

At this point, it needs to be mentioned that due to the EC Competition Rules, it is virtually impossible to conclude cross-border agreements on carrying out the joint tasks (services of general interest in particular) under the current EU legal regulation. It limits the local or regional authorities in granting the right to carry out public service activities to the third party (also to the public law entity). Therefore, in practice, new forms of cross-border cooperation have developed in performing public service activities based on the establishment of an independent legal entity. Then follows the Additional Protocol to the European Outline Convention on Cross-Border Cooperation between Territorial Communities or Authorities (in 1995) that allows local and regional authorities to establish a joint body (an independent legal entity) for cross-border cooperation in carrying out public service activities (Article 4 of the Additional Protocol). Despite the fact that the solution is appropriate, this provision has not been fully implemented in practice, largely because that body must take the legal form that exists within the 
national legal order of one of the participating countries whereby another country can be discriminated.

The preferred solution to this problem, which would eliminate also the issue of references to national law, would be to draft and adopt an EC instrument setting out uniform rules that would apply to the newly established legal entity in the context of cross-border cooperation.

It needs to be emphasised that some attempts at cross-border cooperation in carrying out public service activities have used the European Economic Interest Grouping (EEIG). It can be defined as a supranational legal instrument for participation of two or more companies operating in at least two Member States (in the European economic area). Its duration can be unlimited. And it is formed to facilitate or develop economic activity of its members, and to improve or increase the results of these activities (Van Gerven, 1990: 4). The legal frameworks for the European Economic Interest Grouping were set by the EC regulation No. 2137/85/EGS, and they were adopted by the Council of Ministers on 25 July 1985, effective as from 1 July 1989. The French economic interest grouping, originally called groupement d'intérêt économique (GIE), served as a model for the EGIZ. In the proposal, the Commission selected a regulation as a legal act for the EEIG introduction for the applicability of which no legislative intervention of the Member State is necessary because it can be directly used. Nevertheless, that regulation required specific national implementation. The modalities of implementation vary from country to country. For example, in EEIG documents, the states referred the readers to general rules on legal persons (the Netherlands), to the law governing the national versions of groupement d'intérêt économique (France, Belgium, Luxembourg, Spain, Slovenia) or to the public Trade Association (Germany, Austria). The regulation was implemented either in an independent act or in a broader context. These acts primarily regulated the issues of the grouping registration. The decision over whether or not the EEIG is a legal person is left to them, and whether the Director of the Grouping can be a legal or natural person, and whether or not there are any restrictions on membership, etc.. In addition, the EC regulation explicitly refers us to the application of the national law regarding the issues of restrictions on free competition, social security, labour law, and on intellectual property law. Last but not least, we must not forget the Community's uniform law with which the grouping operation must be harmonized. Among other things, this also applies to the competition law; to the intellectual property law unified to a certain extent; and to the insolvency law that has been unified since 31 May 2002 (Hojnik, 2003: 1899 - 1916).

At this point, we need to note that the EEIG is intended for private partners and that it is not suitable for cross-border cooperation between the local and regional authorities. However, it is true that EEIG could be used as an organisational form for cross-border cooperation in carrying out the joint tasks and it could be adapted 
to the needs of the regional and local authorities. This would be the ideal solution that might eliminate the problems of the joint cross-border carrying out the tasks.

\section{Conclusion}

As we have noticed in this paper, it is of essential importance for efficient carrying out the joint tasks to have an efficient administrative system at the supranational, national and local levels. When carrying out the joint tasks, the local communities can definitely play a key role because they know the needs of the local population, and thus they can contribute to efficient carrying out the joint tasks. However, their ability to perform the joint tasks much more depends on the actual rather than on normative realities of an individual local community. The solution for efficient carrying out the joint tasks primarily lies in various forms of cooperation within the public-public partnerships.

\section{References}

Brezovnik, B. \& Oplotnik, Z. (2003) Fiskalna decentralizacija v Sloveniji (Maribor: Inštitut za lokalno samoupravo in javna naročila Maribor).

Brezovnik, B. (2007) Javno-javno partnerstvo, Revija za javna naročila in javne finance, 2(4), pp. 22-26.

Brezovnik, B. (2008) Izvajanje javnih služb in javno zasebno partnerstvo (Maribor: Inštitut za lokalno samoupravo in javna naročila Maribor).

Brezovnik, B. (2009) Topical Issues on the Legal Regulation of the Public Enterprise in Slovenia, Lex localis - Journal of Local Self-Government, 7(2), pp. 177-195.

Brezovnik, B., Juvan Gotovac, V. \& Bradaschia, N. (2004) Pregled pristojnosti občin, Lex localis - Journal of Local Self-Government, 2(4), pp. 93-201.

Gotovac Juvan, V. (2003) Ustanovitev interesne zveze občin, Lex localis - Journal of Local Self-Government, 1(1), pp. 69 - 87.

Grafenauer, B. (2001) Lokalna samouprava: Teritorialno-organizacijske strukture (Maribor: Pravna fakulteta Maribor).

Grafenauer, B. (2009) An Analysis of the Provision of Local Utility Service by Way of Illustration of Two Slovenian Municipalities, Lex localis - Journal of Local SelfGovernment, 7(2), pp. 209-219.

Hall, D., Lethbridge, J. \& Lobin, E. (2005) Public-Public Partnerships in health and essential services (London: Public Services International Research Unit, University of Greenwich).

Hojnik, J. (2003) Evropsko gospodarsko interesno združenje, Podjetje in delo, 29(8), pp. 1899-1916.

Jerovšek, T. (1994) Razmerja med državo in samoupravo, Javna uprava, 30(1), pp. 45-54.

Levrat, N. (1994) Le droit applicable aux accords de coopération transfrontire entre collectivités publiques infra-étatiques (Pariz: PUF).

Lobin, E. \& Hall, D.(2006) Public-Public Partnership as a catalyst for capacity building and institutional development: Lessons from Stockholm Vatten's experience in the Baltic region (London: Public Services International Research Unit, University of Greenwich). 
Oplotnik, Ž. \& Bradaschia, N. (2005) Primerjalna analiza obsega porabe finančnih sredstev za funkcioniranje mestnih uprav v Sloveniji, Lex localis - Journal of Local SelfGovernment, 3(1), pp. 119-148.

Mrak, M. (2002) Partnerstvo med javnim in privatnim sektorjem: Primer BOT oblike projektnega financiranja. (Ljubljana: Ekonomska fakulteta).

Šturm, L. (ed.) Komentar Ustave Republike Slovenije (Kranj: Fakulteta za podiplomske državne in evropske študije).

Tanzi, V. (2001) Pitfalls on the Road to Fiscal Decentralization (Washington D. C.: Carnegie Endowment for International Peace).

Tanzi, V. (2008) The future of fiscal federalism, European Journal of Political Economy, 24(3), pp. 705-712.

Vandamme, J. (2004) Services of general interest in Europe (Brussels: CoR Studies).

Van Gerven, D., Aalders, C. A. V. (1990) European Economic Interest Grouping; The EEC Regulation and its Application in the Member States of the European Community (Deveter: Kluwer Law \& Taxation Publ.). 